\title{
Cottage economy or collective farm? English socialism and agriculture between Merrie England and the Five-Year Plan
}

Arguments about the production of food are an important yet often neglected feature of socialist literature. Britain is the country where the agricultural revolution happened first, and (with the exception of the United States) went furthest. Perhaps for this reason English socialism has often been caught between an enthusiasm for the egalitarian possibilities of increased production on the one hand and nostalgia for simple peasant agriculture on the other. This paper focuses on two antagonistic models for socialist agriculture, the cottage economy and the collective farm. The first - associated with Romantic, individualistic, anarchistic and medievalist forms of socialism - was the prominent way of imagining socialist agriculture in England during the nineteenth century. The phrase originates in the title of William Cobbett's Cottage Economy, first published in 1822, and Cobbett - with his mixture of radicalism and conservatism - embodies many of the characteristics and contradictions of the later tradition, which sought in various ways to create a free, landowning peasantry. On the continent there were significant parallels in the anarchist thinking of Proudhon, Tolstoy and Kropotkin. The cottage economy resonates later in diverse settings, from the distributism of G. K. Chesterton and Hilaire Belloc to the kibbutz movement, from the agrarian policies of the Khmer Rouge to the fantasies of celebrity chefs; the kitchen garden in Jamie Oliver's Jamie at Home, or Hugh Fearnley-Whittingstall's River Cottage. For advocates of the cottage economy, the emphasis is usually on the quality of the food and the moral benefits of growing it in this way, rather than the statistical measurement of outputs that tends to preoccupy advocates of collective farming.

The collective farm - associated with bureaucratic, utilitarian, statist socialism and above all with the USSR - was largely a theoretical construct until the advent of the Bolshevik revolution. In theory they were owned by the people, and in practice administered by the state. In contrast to the reversion to primitive techniques recommended by Cobbett, William Morris and Edward Carpenter, advocates of collective 
farming gloried in new technology, tractors and efficiency, and instead of small plots, collective farms were to be vast. Industrialised farming techniques would increase yields and reduce labour time. For the Bolsheviks it was the heroes of American capitalism, Taylor and Ford, who held 'the key to a bright and prosperous future'. ${ }^{1}$ This applied as much to agriculture as to industry. The rhetorical justification for collective farming usually emphasised the quantity of food (commonly imagined as 'grain') produced, rather than its quality.

Even this schematic sketch is revealing of the internal dynamics of the socialist movement. Perry Anderson has argued that the history of socialism can be seen as a conflict between the aesthetic, Romantic socialism of William Morris and the 'crassly neo-Benthamite utopia of mechanized industrial regimentation' of Edward Bellamy's Looking Backward. ${ }^{2}$ Anna Vaninskaya makes a similar distinction, linking George Orwell to Morris as part of a Romantic socialist tradition that 'opposes a utopian vision of decentralized democratic community to the evils of rationalist utilitarianism, bureaucracy, and industrial regimentation'. ${ }^{3}$ There is a parallel here to the way in which the (Romantic) cottage economy was opposed to the (utilitarian) collective farm. This essay analyses attitudes to food and farming amongst British writers in the inter-war period, looking at the ways in which experiments with collective farming in the USSR were reported and discussed. My hypothesis is that this was a period in which the collective farm replaced the cottage economy as the centre of gravity for socialist thinking about agriculture and the land. This shift in socialist attitudes to food - from grow-yourown to state provision - relates to a wider shift in the English political imagination, from the Romantic strains of Morris to the more utilitarian ideas of Soviet-style communism and Keynesian social democracy. Those, like Chesterton, Belloc and Orwell, who retained an attachment to the cottage economy were seen (at the very least) as standing outside the mainstream of the socialist tradition, if they weren't dismissed as cranks. The organic movement - and celebrity chefs such as Hugh Fearnley-Whittingstall - are their descendants.

$*$

William Cobbett's Cottage Economy was a manual of practical advice for labourers, showing them how to produce their own food and also stressing the practical and moral benefits of the cottage economy:

from a very small piece of ground, a large part of the food of a considerable family may be raised, the very act of raising it will be the best possible 
foundation of education of the children of the labourer; [. . . it will teach them a great number of useful things [. . .] and give them the best chance of leading happy lives. ${ }^{4}$

Advice to labourers on how to keep bees is not in itself an overtly political programme, but Cottage Economy undoubtedly sees small-scale farming as producing social (as well as edible) goods. Viewed in the context of Cobbett's wider critique of industrialism, it can be seen to form part of a recognisably radical tradition. Cobbett aimed to create (or, as he saw it, restore) a class of free peasant proprietors capable of feeding themselves. The question of who controls the food supply is thus intimately tied up with the question of who owns the land.

The advocacy of peasant smallholding was also a prevalent feature of anarchist thought in the nineteenth century. The 'ideal of a free peasant life was ... a shaping element in Proudhon's social and political thought', for example. ${ }^{5}$ Popular understanding of Proudhon often starts and ends with the phrase 'property is theft', but this claim becomes meaningless when it is taken in isolation from the fundamental theoretical distinction Proudhon makes between 'property' on the one hand - a wholly artificial right and 'the origin of evil on earth' ${ }^{6}-$ and 'possession' on the other, the rightful occupation of a piece of land by a tenant farmer, legitimated through labour. ${ }^{7}$ Possession, for Proudhon, is a natural right deriving from labour that is systematically denied to the labouring class under the capitalist mode of production. He explains:

As a labourer I have a right to the possession of the products of nature and my own industry, but as a proletarian I enjoy none of them. ${ }^{8}$

This assertion of the labourer's natural right to possession over and above the proprietor's merely legal right of property is a key moment in nineteenth-century social thought. Laura Brace has shown that this argument has a longer heritage. John Locke argues in Two Treatises of Government that:

As much Land as a Man Tills, Plants, Improves, Cultivates, and can use the product of, so much is his Property. ${ }^{9}$

Where in Locke this forms the basis of a defence of the enclosures (and therefore the erosion of common land), in Proudhon it becomes a means to assert the right of the agricultural labourer against the propertied class. In a short period - coinciding with the industrial revolution - the philosophical understanding of labour shifted fundamentally. The idea that the land a man tills is his own went from being the philosophical 
basis on which bourgeois property was founded to the starting point of a radical critique of bourgeois property. It had, via Proudhon, a huge impact on the socialist tradition, and its importance for Marxism in particular is often overlooked. ${ }^{10}$

This theory of property was important to advocates of the cottage economy ideal, though not all Romantic socialists saw it this way: the categories are not wholly coincident. Morris undoubtedly fits into the category of Romantic socialism, for example, but for all his admiration for simple peasant life he did not campaign for the rehabilitation of smallholding, arguing instead that both the factory system and the land should be nationalised. ${ }^{11}$ Even so, Morris did not advocate the complete abolition of private possession: he states that socialists 'do not want to share up all wealth: they want all persons to enjoy what they have fairly earned by their labour and what they can fairly $u s e^{\prime}{ }^{12}$ There was sometimes a tension between calls for collectivisation and for smallholdings, then, but the two were not always seen as incompatible. Edward Carpenter argued that:

There are two main directions in which to go in the matter of secure tenure. One is the creation of small freeholds; the other is the throwing of lands into the hands of public authorities, and the creation of permanent tenures under them. Though the latter embodies the best general principle, I do not think that forms a reason for ruling out freeholds altogether. ${ }^{13}$

He proposed a plan involving the creation of many more small freeholds as well as the restitution of the ten million acres of common lands that passed into the hands of landlords as a result of the enclosures. ${ }^{14}$ Carpenter advocates a 'principle of variety' when it comes to land tenure, insisting on the necessity of 'creating not only State and municipal ownership, but ownership by county councils, district councils, parish councils, etc. - with a leaning perhaps towards the more local authorities, because the needs of particular lands and the folk occupying them are likely on the whole to be better understood and allowed for in the locality than from a distance' ${ }^{15}$

Robert Blatchford, whose book Merrie England was central to English socialism in the 1890s, was more definitely arguing for a return to an imagined medieval way of life. He argued that the 'factory system' should be got rid of, and that - contrary to free-trade propaganda - 'the people who depend on foreigners for their food are at the mercy of any ambitious statesman who chooses to make war upon them' ${ }^{16}$ Blatchford made a case for agricultural self-sufficiency, and - drawing on Kropotkin's anarchist vision of a society of peasant smallholders, The Conquest 
of Bread - he argued for more efficient, intensive use of the land, which was to be farmed on small plots.

$*$

The effect of the Russian Revolution on English socialism was profound. Soviet agricultural policy - which tended towards 'large-scale, mechanized agricultural unit[s] producing for the state in the same way as large commercial farms produced for the market in a capitalist system' - altered the terms of the British debate. ${ }^{17}$

Questions of land and tenure were highly important in Russia in the run-up to the 1917 revolution. The land reforms of Petr Arkadevich Stolypin, prime minister of Russia from 1906 until his assassination in 1911, set out to do away with the vestiges of feudalism - serfdom had been abolished as recently as 1861 - by creating a 'new class of conservative peasant landowners' ${ }^{18}$ Stolypin's liberal reform enabled peasants to break away from the medieval mir (peasant commune), which had traditionally held the land in common and divided it up amongst the villagers, and instead establish themselves as small landowners in their own right. G. K. Chesterton (one of the foremost British promoters of the cottage economy ideal after 1917) admired Stolypin's 'policy of peasant proprietorship' as much as he excoriated Bolshevik collectivism. ${ }^{19}$ But the first move for the revolutionary authorities in 1917 was to put off a confrontation with the peasantry by allowing them to seize lands from expropriated landlords, which usually meant a return to the mir. ${ }^{20}$

Though the Russian intelligentsia had idealised the peasantry in the 1870s, the Russian Marxism that emerged as a distinct force in the 1880s was anti-peasant in orientation. Russian Marxism was - in contrast to English Marxism - 'an ideology of modernization as well as an ideology of revolution'. ${ }^{21}$ As a rule, English Marxism (from William Morris to E. P. Thompson) tended to be sceptical of modernisation - i.e. capitalist progress - often seeking to restore the best elements of the pre-capitalist past.

Russian peasants were rarely idealised by English commentators as inhabitants of a version of 'Merrie England'. H. G. Wells describes 'an entirely illiterate peasantry, grossly materialistic and politically indifferent', $^{22}$ and such complaints about the 'backwardness' of the Russian peasantry chimed with Bolshevik propaganda. ${ }^{23}$ Beatrice and Sidney Webb wrote that Russia suffered from 'the least productive of all the peasantries in Europe', citing 'climate', 'race', 'illiteracy' and the nature of the orthodox religion as possible explanations. ${ }^{24}$ '[T] he majority of the Russian mujiks were, in 1900, still in the fourteenth century', they 
complained - ironically, exactly the prelapsarian state that cottage economists wanted to get back to. ${ }^{25}$ John Maynard, one of the key British commentators on Soviet agriculture (and not to be confused with Keynes, mentioned below), argued that:

The Revolution in Russia [. . . ] revealed the normal peasant as the grower of the family food and of the raw materials for the family clothing: and willing to labour for a surplus, only in so far as he was compelled to deliver it up in taxation, or induced to exchange it for vodka or for manufactured commodities. ${ }^{26}$

Left to their own devices, the peasantry would simply divide the countryside up into a honeycomb of peasant smallholdings to be farmed on a subsistence basis. There would be no food for the cities, and the industrial proletariat would starve.

In the long run, the Bolshevik solution to this was collectivisation, but Lenin was (initially, at least) chary about any attempt to collectivise the peasantry by force. ${ }^{27}$ The New Economic Policy (NEP) that ran from the end of the civil war in 1921 up to 1928 included concessions to the peasantry and allowed some capitalist development in the countryside. ${ }^{28}$ Nevertheless, grain requisitioning was commonplace as the Soviet government extracted food from the peasantry in order to feed the urban centres. Keynes, who visited the Soviet Union in 1925, noted that the administration attempted to redress a perceived imbalance between city and country through the control it exerted over the price of food. By setting the price of grain and other foodstuffs well below the world price (while forcing farmers to sell), and setting high prices for industrial products, the authorities were able to 'pamper' the urban proletariat at the expense of the peasantry. ${ }^{29}$

What role should the state play in managing, controlling or even owning the food supply? This question was a live one in Britain in this period, and reports on Soviet agriculture should be seen in the context of this debate. Since the abolition of the Corn Laws in 1846 conventional wisdom dictated that the best system, from the point of view of feeding the poor, was free trade, because it ensured the availability of cheap imported food. ${ }^{30}$ The Labour party itself was staunchly pro free trade throughout the 1920s, and when it started to offer support for a more interventionist state the example of Soviet Russia was a key element. ${ }^{31}$

But by then a deeper shift had already taken place. The Great War that helped to precipitate and coincided with the Bolshevik revolution saw a significant expansion of the British state, as a percentage of GDP and in terms of its executive powers, conscription being the most keenly felt. ${ }^{32}$ A state that had sent its young men to die in France was increasingly seen as having a reciprocal responsibility towards its citizens: calls for 
state provision of healthcare, housing and unemployment benefit were starting to be heard..$^{33}$ In terms of food, a new feeling that the state had a vital role to play in managing and regulating its supply was an important feature of the inter-war period. Free trade's claim to be able to alleviate poverty was based on the supply of cheap imported food, but after the war the emphasis of the popular debate moved from the price of food to its healthiness. Frank Trentmann writes:

Talk of 'necessaries', so vital to the public appeal of Free Trade in the Victorian and Edwardian period, now moved away from a liberal defence of markets and cheapness to a more social-democratic focus on public health. To be a citizen meant to have access to 'essential' food, which states should provide at fair prices. Cheapness, in other words, no longer prevented malnutrition. ${ }^{34}$

Milk was a key commodity in this shift: governmental intervention began with the Milk and Dairies Order in 1901, which established minimum levels of butterfat and non-fat solids below which milk was considered to be adulterated and unfit for sale. Legislation gathered momentum after the Great War, in the context of a wave of infant mortality caused by infected milk in hospitals, resulting in public pressure for the state to regulate the supply. ${ }^{35}$ This was part of a movement which tended to emphasise that 'What mattered now was not so much what food cost as what was in it': the state had a new role to play in ensuring the quality of food. ${ }^{36}$ The Milk Control Board was established in 1918, and 'the state was on the point of taking over the entire wholesale milk trade' ${ }^{37}$ In Britain, the increased collectivisation of the food supply was all about guaranteeing the quality of produce, and as such it drew on native traditions of English socialism as much as it reminded many of the Soviet experiment.

The Fabian Society had, in the Edwardian period, been preparing the ground for the increased intervention of the state into questions of food. Hubert Bland's 1905 tract on the state feeding of school children argues that 'all children, destitute or not, should be fed, and fed without charge, at the expense of the State or Municipality'. ${ }^{38}$ For Fabians, the regulation of various foodstuffs would not be enough to guarantee their safety; public ownership was what was required, and milk was again at the heart of the debate. F. Lawson Dodd's Fabian Tract Municipal Milk and Public Health drew a comparison with the regulation and then nationalisation of the water supply: 'mere external interference was insufficient, and hence a movement became general towards investing the ownership as well as the control of the water supplies of the country in the hands of the community'. ${ }^{39}$ Dodd's proposals were explicitly opposed to the free-trade orthodoxy which then had mass public support: 'It is only 
necessary to convince the public that it can no longer afford to drink dirty and expensive milk in order to support its adherence to a worn-out and obsolete economic theory'.$^{40}$ Hilaire Belloc - a key ally of Chesterton's, a distributist and an advocate of the cottage economy - saw the retail urban milk trade as the 'typical illustration' of 'one of the stock arguments of Communism'.

Your Fabian bewailed the state of affairs in which two small men, each with the goodwill of a milk walk overlapped. He pointed out that the expenses of distribution would be vastly reduced by one system controlling the whole mass of small milk walks as they existed not so long ago. He has lived to see the thing come about, in this country at least; for the small man in the milk trade has almost disappeared. A huge monopoly has swallowed him up. ${ }^{41}$

Belloc was concerned to defend the small distributor, as much as the small producer, against large monopolies. Whether monopolies were owned by the state or by capitalists, for Belloc the effect was the same. This perspective is integral to the cottage economy's dual critique of capitalism and collectivism. Belloc saw communism not just as something that is 'over there' in Russia, but as a real tendency within British life and one, moreover, that 'moves along the same lines as Capitalism' ${ }^{42}$

$*$

In Russia at the end of the 1920s, the Bolsheviks felt caught between the medieval backwardness of the 'tradition-bound mir' and the 'peasant capitalism' - with its emphasis on smallholding - that had gathered pace with the Stolypin reforms and under NEP. ${ }^{43}$ Stalin's solution, as he explained it in May 1928, was to 'transfer from small, backward and fragmented peasant farms to consolidated, big, public farms, provided with machines, equipped with the data of science and capable of producing the greatest quantity of grain for the market ${ }^{\prime}{ }^{44}$ In reality, collectivisation often involved more compromises with existing peasant institutions and with the past than this implies - ironically peasants often saw it as a second serfdom - but the regime represented collectivisation in these uncompromisingly modernising terms and this is how British observers tended to understand it. ${ }^{45}$

Communist ideas about the struggle in the countryside are reflected in Sergei Eisenstein's The General Line (1928), where intransigent peasants resist the attempts of a leather-clad Bolshevist to modernise their farming methods. One telling sequence sees a piece of open pasture fade into an image of the same land divided by wooden fences into tiny plots. 

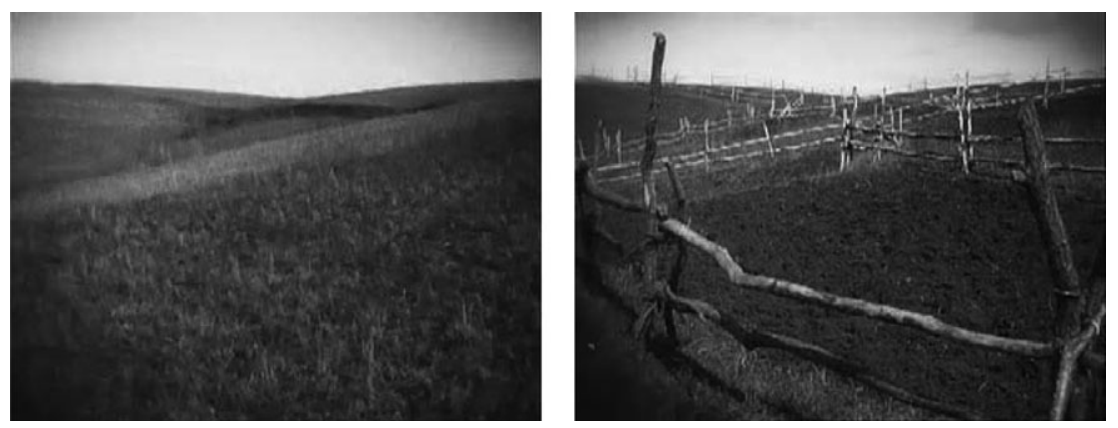

Sergei Eisenstein, The General Line (a.k.a. Old and New)

The fully mechanised collective farm wins out in the end, in a memorable sequence in which tractors - the ultimate image of Soviet agriculture - crash through the wooden fences, dispensing with the terrain of the peasant smallholder and inaugurating the huge collective farm. The film was seen in Britain and reviewed by Bryher in Close Up: it may not have matched up to Battleship Potemkin visually, she thought, but she had 'no quarrel with the sociological import of the film', approving of its 'vision of Russia covered with tractors'. ${ }^{46}$
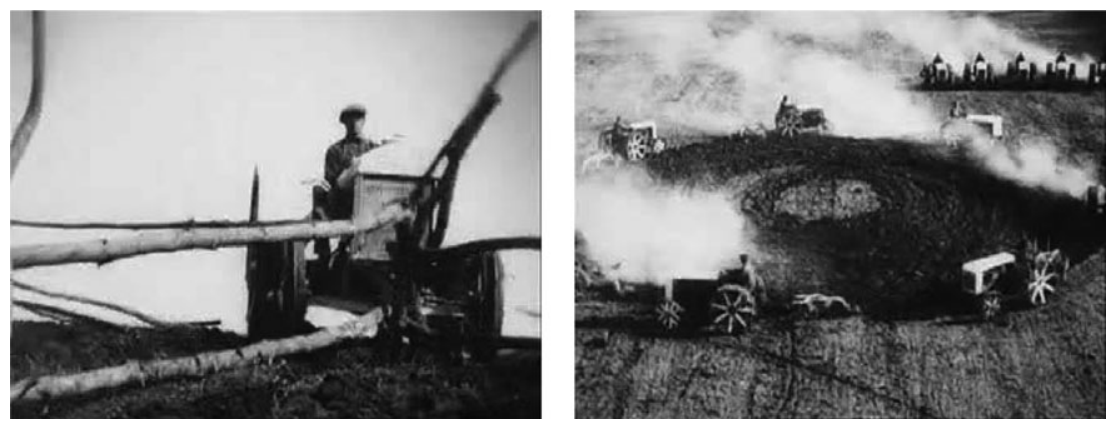

Sergei Eisenstein, The General Line (a.k.a. Old and New)

Eisenstein's film was made at a transitional point in the history of Soviet agriculture. The consensus under NEP was that peasants would voluntarily collectivise themselves, but by 1928 only 1.2 per cent of the total sown area of the USSR was taken up by collective farms (kolkhozy). Kulaks - prosperous peasants who had benefited from Stolypin and from NEP - were increasingly blamed for hoarding, and in 1929 the free market in grain was completely eliminated as Stalin announced 'the liquidation of the kulaks as a class' and the party committed itself to a policy of all-out forcible collectivisation. ${ }^{47}$ The agricultural revolution in 
England took centuries, but the expropriation of the peasant population was its most painful effect, and one of the key elements of capitalism that Cobbett and Marx responded to. ${ }^{48}$ The collectivisation of the Russian countryside was like the enclosures all over again, compressed into a brutal four years. This time, however, socialists were being asked to cheer on the expropriation of 'kulaks' in the name of progress.

British discussions of the Soviet collectivisation drive suggest a significant shift in the attitudes of English socialists towards the state. Postwar turmoil, compounded by the effects of the great depression, led to a loss of faith in the market, and many turned to the state to take a more active role in the production, distribution and regulation of the food supply. The ideal of the free peasant proprietor - like those 'kulaks' who were being persecuted in Russia - no longer held a central place in the socialist imagination.

In fact, those - like Hilaire Belloc and G. K. Chesterton - who clung on to this ideal tended not to be classified as socialists. Chesterton was happy to call himself a socialist in the 1890s, but not later on - yet it was largely socialism that had changed, not his own political project. Chesterton admired William Morris but could not fathom why he might have called himself a socialist. It was impossible to imagine that Morris 'would have tolerated for ten seconds the vast industrial materialism of the Five-Year Plan'. ${ }^{49}$ Instead, Chesterton started to see Mussolini's fascism as the best political means to achieve his objectives. ${ }^{50}$ A. J. Penty followed a similar trajectory from disciple of Morris in the Edwardian period, through guild socialism, and finally to the belief that the 'Regulative Guild State' he desired had come into being in Mussolini's Italy. ${ }^{51}$ Again, the constant was the belief in 'a local life... rooted in local traditions', a revival of 'the corporate life of the Middle Ages'.$^{52}$ During the years in which the USSR dominated debates about socialism, to believe in the 'cottage economy' was generally to be seen as a fascist, a Catholic or a crank.

Some in this group were quick to notice the authoritarian potential of collective farming. The Communist government itself referred to the grain requisitions of the civil war period as part of a 'food dictatorship'. ${ }^{53}$ '[F]ood is a weapon' was Litvinov's mantra during the famine of 1921, as Harold Henry Fisher noted. ${ }^{54}$ The potential for the state control of the food supply to be put to authoritarian uses was heavily linked to Soviet Russia in the British debate. In 1932, Rev. Ronald Knox - a Catholic and a Chestertonian advocate of a society of peasant smallholders - published a mock-up of a hypothetical edition of The Times under the title 'If the General Strike had Succeeded' in a volume of counterfactual history called If It Had Happened Otherwise. Knox's contribution comprised various stories about and reflections on the establishment of a 
communist state in Britain, including two fictional letters to the editor about the 'Milk Pool in Hyde Park'. The imagined communistic government has developed a system of storing milk in a huge pool in Hyde Park, to the extent where, as one aggrieved correspondent puts it, 'several suburbs entirely depend on it for their daily supply'. This stateowned milk supply is 'a weapon' with which the government 'can threaten, if its authority should at any time be defied, to starve London into obedience'. ${ }^{55}$ Knox's fears over the nationalisation of the food supply tapped into the public discourse around the Soviet state farms, and there is an implicit link to the recent establishment of the Milk Board in Britain.

As a substance that plays a key role in binding an infant to its mother, milk was a particularly evocative commodity. If the state was taking control of the nation's milk, was it in some ways stepping into the role of the mother, and breaking up the institution of the family? In The Sleeper Awakes (first published in 1899 as When the Sleeper Wakes) H. G. Wells depicts a dystopian future in which the nursing of children is controlled by the 'International Crèche Syndicate'. The wet nurses in this world are robots,

a vista of mechanical figures, with arms, shoulders and breasts of astonishingly realistic modelling, articulation, and texture, but mere brass tripods below, and having in the place of features a flat disc bearing advertisements likely to be of interest to mothers. ${ }^{56}$

Huxley took up this theme in Brave New World, a novel deeply worried about the expansion of the state's functions. Here, all aspects of child rearing have been collectivised. Mustapha Mond thinks back to the bad old world, where

Maniacally, the mother brooded over her children (her children)... brooded over them like a cat over its kittens; but a cat that could talk, a cat that could say, 'My baby, my baby,' over and over again. 'My baby, and oh, oh, at my breast, the little hands, the hunger, and that unspeakable agonizing pleasure! Till at last my baby sleeps, my baby sleeps with a bubble of white milk at the corner of his mouth. My little baby sleeps ...'

'Yes,' said Mustapha Mond, nodding his head, 'you may well shudder. ${ }^{57}$

In Huxley's dystopian future - and perhaps implicitly in Russia - milk is administered by the state, and not by the mother: a disturbing indicator of authoritarianism. Half a century later, Margaret Thatcher - who accused the welfare state of breaking up families by usurping various functions that properly belonged to parents - was referred to by socialists as 'Maggie Thatcher Milk Snatcher' when she abolished the provision of free milk in British schools. ${ }^{58}$ This demonstrates just how far the 
British left had moved from its Romantic agrarian roots. The state's interventionist role in administering food (and in child rearing) is seen not as a dystopian nightmare, but as a de facto good. ${ }^{59}$

Other critiques of collective farming responded to actual conditions in the Russian countryside. In the years 1932-4, one of the worst famines in human history swept the USSR. Estimates as to the death toll vary, but five million is probably roughly accurate.$^{60}$ And yet, despite the appearance of first-hand reports by Malcolm Muggeridge and Gareth Jones in the Manchester Guardian which prompted further coverage across the print media, a significant portion of the British intelligentsia ignored or denied it. ${ }^{61}$

In Soviet Communism: A New Civilization, the Webbs attribute all talk of a man-made famine to 'persons hostile to the Soviet Union'. ${ }^{62 ~ ' W h a t ~}$ the Soviet Government was faced with', they wrote, 'was, in fact, not a famine but a widespread general strike of the peasantry, in resistance to the policy of collectivization, fomented and encouraged by the disloyal elements of the population' ${ }^{63}$ Although off the mark, their analysis was not a complete fiction: as Fitzpatrick puts it, "The famine of 1933 was the consequence of an irresistible force (the state's demand for set quotas of grain) meeting an immovable object (the peasants' stubborn passive resistance to these demands) ${ }^{\prime}{ }^{64}$ But this was not merely the resistance of peasant smallholders who wanted to farm at subsistence levels. It was the resistance of starving people who did not wish to relinquish what little grain they had, often - as Muggeridge noted in the Manchester Guardian - for it to be exported to Western Europe. ${ }^{65}$ In Winter in Moscow, a harrowing novel about western journalists in Russia at the time of the famine, Muggeridge describes the horrible story of a peasant family whose last bag of flour is requisitioned. The delirious mother kills her children and puts their bodies in sacks, before surrendering them as grain and killing the man sent to collect them. ${ }^{66}$ Muggeridge writes that 'Bolshevism, like an enormous stomach, threw out digestive juices and assimilated the affair', ${ }^{67}$ and goes on to describe how these events are reported in the Soviet press as 'Symptomatic of new tactics of kulak elements'. ${ }^{68}$

The Webbs argued that the Soviet government attempted 'so drastic ... , so hazardous an experiment' because 'there was no other course open to them' ${ }^{69}$ But their endorsement of the collective farm is unambiguous, and comes with a direct critique of smallholding. Here they reflect on the task facing the Communist authorities: 
To convert, within less than a decade, even two thirds of a population of 120 millions of peasantry steeped in ignorance, suspicion and obstinacy, accustomed for centuries to individual cultivation of the little holdings that they now deemed their own, with all the cunning and greed that such a system develops, into public-spirited cooperators working on a prescribed plan for a common product to be equitably shared among themselves, might well have been deemed hopelessly impracticable. ${ }^{70}$

What is at stake here is not merely the 'backwardness' of the Russian peasant, but the whole principle of peasant smallholding. The Webbs collapse the distinction between peasant capitalism (along the lines promoted by Stolypin and by NEP) and the attachment to the medieval mir. Both are seen as versions of the cottage economy, which is indicted as an encouragement to 'cunning and greed', and the collective farm is promoted as the cure. ${ }^{71}$ The Fabian commitment to the principle of collective ownership of agricultural land and of the food supply predated the Bolshevik revolution: perhaps the only way of holding onto the ideal in the period of actually existing collective farming was to insist that it was working, and blame any shortages on kulaks or peasant backwardness.

Fabians defended the collective farm as it had been conceived in the Edwardian period, but there were also socialists who criticised collectivisation in the spirit of Merrie England and the cottage economy. For George Orwell, for example, a defence of the small farmer and a hatred of industrialised food ('making sausages out of fish, and fish, no doubt, out of something different ${ }^{\prime 72}$ ) formed part of his desire to keep decency alive in the face of industrial modernity. His treatment of the famine in Animal Farm is understated by comparison with Muggeridge's Winter in Moscow, but it shows his hostility towards collective farming, not just in practice but also in theory. Napoleon - the pig who represents Stalin in the story - tries to conceal the food shortage: sheep are instructed to remark within hearing of a human visitor that their rations have been increased. Empty bins are filled with sand and topped with grain to give the impression of abundance to neighbouring farmers. ${ }^{73}$ When the hens are instructed to surrender their eggs, which are to be sold off the farm at a time of famine, Napoleon says that they 'should welcome this sacrifice as their own special contribution towards the building of the windmill' ${ }^{74}$ But the hens protest by laying their eggs while perched high on the rafters, causing them to fall and smash on the floor below. The rebellious hens are later slaughtered. ${ }^{75}$

As well as targeting the brutal coercion that Stalin's regime used in what Muggeridge termed a 'war between the government and the peasants $^{\prime},{ }^{76}$ Orwell's satirical presentation of these events raises questions about whether the state has the right to control the food supply. The 
political philosophy of animalism, elaborated at the beginning of Animal Farm by Old Major, complained that 'nearly the whole produce of our labour is stolen from us by human beings' ${ }^{77}$ One could retort that this is just the necessary character of agriculture in a partially urbanised society: whether prices are set by a cartel of supermarkets or by the state, the net effect is that farmers have to surrender a large proportion of their produce, and (except for very large landowners who in any case do not work the land themselves) they rarely end up rich. The central contention of Orwell's satire is that the pigs take over from the humans - the communist state exploits the peasantry in exactly the same way as capitalist landowners or the old tsarist autocracy did. Neither achieves the implicit goal of allowing farmers to own their produce and eat it: 'live of your own', as Belloc put it. ${ }^{78}$

The idea that the Soviet farm was a version of the large capitalist farm had a certain currency in the period. The Economist noted that 'The present Sovhos [state farm] is a big mechanised estate run on commercial lines similar to those on which big estates are conducted in the U.S.A. and other capitalist countries' ${ }^{79}$ For those like Muggeridge and Orwell who were critical of collective farming from a socialist perspective, the comparison of the state farm with capitalist agriculture was an important rhetorical strategy. As Muggeridge wrote, the Bolsheviks' 'dreams and plans were essentially urban; proletarian Big Business; Marx-Ford Bourneville' ${ }^{80}$ Collectivism was simply monopoly capitalism, with the state taking the place of the capitalists at the top of the oligarchy, as Chesterton and Belloc had been arguing since the Edwardian period. In The Outline of Sanity Chesterton wrote that

when capital has come to be too much in the hands of the few, the right thing is to restore it into the hands of the many. The Socialist would put it in the hands of even fewer; but those people would be politicians, who (as we know) always administer it in the interests of the many. ${ }^{81}$

Whom does Chesterton mean by 'the few'? Well, there is almost certainly an anti-Semitic subtext here. His point, though, is that nobody, least of all politicians, could be trusted to administer the agricultural land except the peasants themselves. There is little to differentiate the functionary in charge of the kolkhoz from the capitalist landowner.

Muggeridge took a similar view: 'the dictatorship of the proletariat decrees the abolition of property and thereby creates a situation in which the most vile manifestation of the instinct to possess can have free play $^{\prime}$, he wrote. ${ }^{82}$ And Winston Smith encounters a similar argument in Orwell's Nineteen Eighty-Four, when he reads Emmanuel Goldstein's 
Theory and Practice of Oligarchical Collectivism (a fictional critique of the authoritarian state the novel depicts). Goldstein writes:

It had long been realized that the only secure basis for oligarchy is collectivism. Wealth and privilege are most easily defended when they are possessed jointly. The so-called 'abolition of private property' which took place in the middle years of the century meant, in effect, the concentration of property in far fewer hands than before: but with this difference, that the new owners were a group instead of a mass of individuals. Individually, no member of the Party owns anything, except petty personal belongings. Collectively, the Party owns everything in Oceania, because it controls everything, and disposes of the products as it thinks fit. In the years following the Revolution it was able to step into this commanding position almost unopposed, because the whole process was represented as an act of collectivization..$^{83}$

Those who saw the dangers of collectivism from the left often wanted to reassert a kind of connection with the soil that the collective farms had destroyed. Muggeridge explained that Soviet agricultural policy was 'inconceivable and horrible to anyone having even a remote connection with earth, with the seasons, with the labour of sowing and the joy of harvest; plausible enough in some stuffy café or committee room' ${ }^{84}$ While Orwell was writing feverishly about Stalinism, he was also trying patiently to establish himself as a Suffolk smallholder. His domestic diaries record in detail the number of eggs his hens had laid, how many pints of milk his goat Muriel had yielded, and when to plant his peas, beans and potatoes. He seems also to have been a subscriber to the Smallholder, a magazine to which he makes frequent reference. ${ }^{85}$

Important distinctions exist between the various thinkers for whom the peasant smallholder became a bulwark against the Soviet collective farm. Orwell was certainly critical, for example, of those popular advocates of the cottage economy as a political project, who - like Chesterton and Roland Knox (who wrote about the milk pool in Hyde Park, and whom Orwell mocked) - were Catholics or fascists. ${ }^{86}$ Orwell's criticisms of Soviet collectivism share some important features with Chesterton's, but he wanted to defend a properly socialist version of the cottage economy that was neither Catholic nor fascist.

There were also those on the British left who celebrated the Soviet farms in their own terms: if they bore similarities to American capitalist ranch farming, then so much the better - this was the most modern and efficient arrangement and would no doubt yield more 'grain'. Joan Beauchamp, for example, a suffragette and co-founder of the Communist Party of Great Britain, made the standard comparison with America in her book Agriculture in Soviet Russia. Unlike Orwell and Muggeridge, though, she did not see this as an indictment of collective farming. She 
noted approvingly that the director of the Verblud (a state farm) 'spent a year in Canada and the U.S.A. studying large-scale farming methods' ${ }^{\prime}{ }^{87}$ Moving on to the Gigant, 'the largest farm in the world' at 450,000 acres, she praised the way it was 'completely mechanised as far as the actual cultivation is concerned' ${ }^{88}$ She continued: 'The director of Gigant told me that he considered himself the richest man in the world, for "his" farm is four times the size of the biggest farm in America. ${ }^{89}$ What is surprising is that a British socialist, traditionally so critical of Fordist industrialism, could find this appealing.

If Muggeridge and Orwell tapped into traditions of Romantic socialism that sought to enact a return to the land, there was also an emerging debate within the realm of agricultural science that advanced technical as well as moral reasons for advocating smallholdings. The organic movement emerged partly as a way of perpetuating the idea of the cottage economy in a period when most socialists had come to believe in the necessity of the mechanised collective farm. At Faber and on the editorial board of A. R. Orage's New English Weekly, T. S. Eliot played an important role in publishing key texts by early advocates of organic farming such as G. T. Wrench, Anthony Howard and his wife Louise Howard. ${ }^{90}$ Alexandra Harris has recently explored Eliot's interest in agriculture in the 1930s: as she points out, he wrote in the Criterion that 'the greater part of the population, of all classes [. . .] should be settled in the countryside and dependent on it'. ${ }^{91}$ Harris is quick to link Eliot's advocacy of the cottage economy ideal - via his correspondence with the conservative agriculturalist Viscount Lymington - to 'Hitler's analogous fight for the pure soil of Germany'.$^{92}$ Lymington undoubtedly shared the cottage economy analysis of the Soviet Union:

In Russia the hammer has been discarded for the conveyor belt, and the sickle for the combine harvester-thresher. The former are the symbols of human effort against nature, the latter are the chains that enslave man to the machine. ${ }^{93}$

But Eliot's interest in agriculture also involved contact with agriculturalists like Louise Howard (née Matthaei), who were very much on the left as well as advocating a return to the soil. Howard was pro Sparticist in the twenties, worked on the International Review with Leonard Woolf, and made strenuous efforts to help German refugees from Nazism. ${ }^{94}$ The wider context of the cottage economy discourse to which I have drawn attention, moreover, helps to show that the demand to go 'back to the land', while undoubtedly forming an important element of fascism, is socialist and anarchist in origin. This is not a simple left/right issue.

The organic movement, which had strong links with the modernist intelligentsia through the likes of Eliot, Louise Howard and Orage, was 
as much a rejection of Soviet agriculture as a critique of capitalist farming. In Reconstruction By Way of the Soil - published by Eliot at Faber - G. T. Wrench sees the mechanisation of farming in the USSR as contributing to soil erosion. He vilified the tractor, 'the visible image of the inner belief in the machine as a saviour' and 'heralded as a propagandist' for collective farming in the USSR. ${ }^{95}$ In this book Wrench advocates 'The restoration of the peasantries and peasant families as the cardinal cultivators of the soil'. ${ }^{96}$ Wrench's work, which was central to the development of the organic movement, can tell us a lot about the peculiar politics of its present-day acolytes, who have been destined to be cut off from socialism ever since the official left plumped for Stalinist collective farming in the 1930s.

$*$

Perhaps the most interesting British responses to the collective farm that I have discovered are the following. Writing - perhaps crucially - after the signing of the Anglo-Soviet Pact, Margaret Cole argued that Russia benefited from

a communal village association which preserved in Russian agricultural life a tradition of collective responsibility which had been lost in England since the last Labourers' Revolt ended in the graves at Micheldever. This tradition, passing through many vicissitudes, has proved the basis for the collective farm and rural soviet organisation which is so strongly established today. ${ }^{97}$

Cole is writing from a statist, pro-Soviet, Fabian perspective, but she also manages to describe the kolkhoz as if it was a continuation of the medieval peasant farming that had died in England at the time of the enclosures. Here the Russian peasant was not imagined as holding back the progress of socialism - on the contrary, his backwardness was to be celebrated as the foundation for the socialist organisation of the countryside.

This was a debate that had been an element of Russian socialism since the nineteenth century. The Narodniks - the 'People's Party', which was an important anti-tsarist force in late nineteenth-century Russia - held that the mir would form the basis for peasant socialism, and that the capitalist phase of agricultural development could be skipped altogether. ${ }^{98}$ Even Engels predicted in On Social Relations in Russia that 'the system of communal property in today's Russia can serve as a point of departure for the development of communism' ${ }^{.9}$ But Lenin rejected this analysis in the 1890s as 'economic Romanticism', advocating capitalism 
instead as a necessary, albeit painful, step on the way to socialism. ${ }^{100}$ The Communist party broadly followed Lenin's line in aggressively promoting industrial progress, but there was a medievalist strand in Russian socialism for those who, for their own reasons, needed to find it.

Joan Beauchamp, as I have demonstrated, was keen to show how the Russian collective farm could outdo the American ranch in terms of efficiency and output. But in a bizarre twist, she also wanted to see it as a fulfilment of the dreams of Merrie England that had captivated English socialists in the 1880s and 1890s. Describing a visit to a large sovkhoz (state farm), she writes:

My train arrived at Ubokaya, a village which used to be in the Ukraine but is now included in the Northern Caucasus, at 9.30 in the morning just in time to catch a glimpse of a curious and interesting ceremony. The collective farms of the district had already gathered their harvest and were bringing their grain to the railway. An avenue had been made of brilliant red banners with such legends as 'A Present to the Soviets from the Collective Farms,' 'Socialised Grain for the People,' 'The Five Year Plan in Four Years' and other slogans. Down the avenue under the banners came an endless procession of wagons each drawn by two bullocks, beautifully garlanded and well groomed for the occasion. The wagons were piled high with sacks of grain and attended by women and children in gay frocks and festive decorations. Trains, alas, do not wait on ceremony, and I was reluctantly forced to leave these village rejoicings, but I felt that at last I had seen something not unlike the legendary 'Harvest Homes' of Merrie England, which have now in my native Somersetshire dwindled into the dull and formal Harvest Festival of the village church. ${ }^{101}$

This is extraordinary. On the one hand one could try to dismiss it as another instance of a 'useful idiot' duped by a Potemkin display of opulence along the lines of Orwell's barrels of grain-topped sand. But the image is so evocative - so powerful. Beauchamp is no longer trading in the official utilitarian language of efficiency and output - this is the Romantic rhetoric of Merrie England in full swing. The Russian countryside has become a kind of fantasy space where the contradictions between Romantic socialism and utilitarian socialism, between Merrie England and the Five-Year Plan, and between the cottage economy and the collective farm can be resolved.

*

Where does this leave us? The opposition between Romantic and utilitarian socialism has become, partly as a result of the debates I have described, a profoundly asymmetrical dialectic, where the language of 
politics (socialist included) is almost entirely utilitarian, and what is left of the cottage economy ideal has been drained of political content. We (and I suppose I should admit that this is a broadly middle-class 'we') grudgingly accept the argument that intensive, industrialised farming is necessary in a heavily urbanised society. But our behaviour - buying organic, watching River Cottage, salivating over the increasingly sumptuous food porn that fills the weekend supplements - reaches towards the cottage economy ideal as if to compensate for the grinding utilitarianism of political debate. The current media obsession with food speaks to an interest in quality of which Merrie Englanders Cobbett, Belloc, Chesterton and Orwell would have approved, even if they saw this as part of a more properly political project. The true synthesis that Perry Anderson found in Marx, and that Joan Beauchamp saw with her own deluded eyes in the sovkhoz, seems an increasingly unlikely outcome.

\section{Notes}

I should like to thank Professor Morag Shiach for commenting on an earlier draft of this paper, and the Leverhulme Trust for funding the research project from which this paper derives.

1 Orlando Figes, A People's Tragedy: The Russian Revolution, 1891-1924 (London: Jonathan Cape, 1996), 744.

2 Perry Anderson, Arguments within English Marxism (London: NLB and Verso Editions, 1980), 169.

3 Anna Vaninskaya, 'Janus-Faced Fictions: Socialism as Utopia and Dystopia in Willam Morris and George Orwell', Utopian Studies, 14:2 (2003), 83-98 (p. 84).

4 William Cobbett, Cottage Economy; Containing Information Relative to the Brewing of Beer, Making of Bread, Keeping of Cows, Pigs, Bees, Ewes, Goats, Poultry, Etc (London: C. Clement, 1822), 8-9.

5 George Woodcock, Anarchism: A History of Libertarian Ideas and Movements (Harmondsworth: Penguin, 1986), 93.

6 P. J. Proudhon, What Is Property? (Cambridge: Cambridge University Press, 1994), 75.

7 Ibid., 36; Laura Brace, The Politics of Property: Labour, Freedom and Belonging (Edinburgh: Edinburgh University Press, 2004), 120-21.

8 Proudhon, What Is Property?, 36.

9 Quoted in Brace, The Politics of Property, 28.

10 In The Holy Family, Marx called Proudhon's What Is Property? 'the first decisive, vigorous, and scientific examination of property'. Quoted in Woodcock, Anarchism, 95.

11 William Morris, 'What Socialists Want', in The Unpublished Lectures of William Morris (Detroit: Wayne State University Press, 1969), 217-33, 228-9.

12 Ibid., 227. 
13 Edward Carpenter, The Village and the Landlord (London: Fabian Society, 1907), 8.

14 Ibid., 10-11.

15 Ibid., 8.

16 Robert Blatchford, Merrie England (London: Clarion, 1894), 35.

17 Sheila Fitzpatrick, Stalin's Peasants: Resistance and Survival in the Russian Village after Collectivization (New York and Oxford: Oxford University Press, 1994), 39.

18 Figes, A People's Tragedy, 227.

19 G. K. Chesterton, The Appetite of Tyranny (Kila MT: Kessinger, 2004), 19.

20 Sheila Fitzpatrick, The Russian Revolution (Oxford: Oxford Uiniversity Press, 2008), 56.

21 Ibid., 25-6.

22 H. G. Wells, Russia in the Shadows (Hodder \& Stoughton: London, 1920), 88.

23 Sheila Fitzpatrick, Everyday Stalinism: Ordinary Life in Extraordinary Times: Soviet Russia in the 1930s (New York and Oxford: Oxford University Press, 1999), 9-10.

24 Beatrice Webb and Sidney Webb, Soviet Communism: A New Civilization (London: Victor Gollancz, 1937), 236.

25 Ibid., 236n.

26 John Maynard, 'Collective Farming in the Ussr', Slavonic and East European Review, 15:43 (July 1936), 47-69 (p. 50).

27 C. L. R. James, World Revolution 1917-1936: The Rise and Fall of the Communist International (London: Secker \& Warburg, 1937), 300.

28 Fitzpatrick, The Russian Revolution, 96.

29 John Maynard Keynes, A Short View of Russia (London: Hogarth, 1925), 20-21.

30 Frank Trentmann, Free Trade Nation: Commerce, Consumption, and Civil Society in Modern Britain (Oxford: Oxford University Press, 2008), 213-14.

31 Ibid., 311, 343.

32 Roger Middleton, 'The Size and Scope of the Public Sector', in The Boundaries of the State in Modern Britain (Cambridge: Cambridge University Press, 1996), 93, 96.

33 On housing, see Matthew Taunton, Fictions of the City: Class, Culture and Mass Housing in London and Paris (Basingstoke: Palgrave Macmillan, 2009).

34 Trentmann, Free Trade Nation, 214.

35 Edith Holt Whetham, The Agrarian History of England and Wales, vol. 8, 1914-39 (Cambridge: Cambridge University Press), 25.

36 Trentmann, Free Trade Nation, 220.

37 Ibid., 203.

38 Hubert Bland, "'After Bread, Education": A Plan for the State Feeding of School Children (Fabian Tract, no. 120)', (London: Fabian Society, 1905), 9.

39 F. Lawson Dodd, Municipal Milk and Public Health (London: Fabian Society, 1905), 3.

40 Ibid., 18. 
41 Hilaire Belloc, 'The Restoration of Property: II - the Handicap against Restoration', English Review, 56:2 (February 1933), 169-82 (p. 174).

42 Ibid., 170.

43 Fitzpatrick, Stalin's Peasants, 28-9.

44 Cited in Fitzpatrick, Stalin's Peasants, 39.

45 Ibid., 128-9.

46 Bryher, 'Preview of the General Line', Close Up, 6:1 (January 1930), 34-9 (p. 38).

47 Fitzpatrick, Everyday Stalinism, 26.

48 See William Cobbett, Rural Rides (London: Penguin, 2001). Marx's chapters on the expropriation of the rural population are in Karl Marx, Capital: A Critique of Political Economy (London: Lawrence and Wishart, 1974), 671-701.

49 G. K. Chesterton, As I Was Saying: A Book of Essays (London: Methuen \& Co., 1936), 128.

50 William Empson, quoted in George Orwell, I Have Tried to Tell the Truth, 1943-1944 (London: Secker \& Warburg, 2001), vol. 16, 443-4.

51 Philip Conford, The Origins of the Organic Movement (Edinburgh: Floris Books, 2001), 154.

52 Arthur Joseph Penty, Means and Ends (London: Faber \& Faber, 1932), 55, 67.

53 S. A. Smith, The Russian Revolution: A Very Short Introduction (Oxford: Oxford University Press, 2002), 77.

54 Harold Henry Fisher, The Famine in Soviet Russia, 1919-1923: The Operations of the American Relief Administration (New York: Macmillan, 1927), 62.

55 Roland Knox, 'If the General Strike Had Succeeded', in If It Had Happened Otherwise (1932; London: Sidgwick \& Jackson, 1972), 277-89 (p. 285).

56 H. G. Wells, The Sleeper Awakes (London: Penguin, 2005), 183.

57 Aldous Huxley, Brave New World (London: Vintage, 2004), 31-2.

58 Tony Judt, Postwar: A History of Europe since 1945 (London: Heinemann, 2005), 540.

59 The objection that increased state intervention in the food supply might usurp the role of the mother and so 'disintegrate the home' had been anticipated by its Fabian advocates in the Edwardian period. See Bland, "“After Bread, Education": A Plan for the State Feeding of School Children (Fabian Tract No. 120)', 10-11 Bland argues that, on the contrary, municipal school dinners would 'civilize and humanize the children, who would learn what a dinner ought to be'.

60 The various sources relating to the famine are well sifted in Dana G. Dalrymple, 'The Soviet Famine of $1932-4$ ', Soviet Studies, 15:3 (January 1964), 250-84.

61 Muggeridge's reports appeared in the Manchester Guardian on 25, 27 and 28 March 1933. There is a useful archive of Jones's writings on Russia at http:/ / www.garethjones.org/soviet_articles/soviet_articles.htm.

62 Webb and Webb, Soviet Communism, 258.

63 Ibid., 265.

64 Fitzpatrick, Stalin's Peasants, 5. 
65 Malcolm ['A Correspondent'] Muggeridge, 'The Soviet and the Peasantry: An Observer's Notes. I: Famine in North Caucasus: Whole Villages Exiled.', in Manchester Guardian (25 March 1933), 13-14.

66 Malcolm Muggeridge, Winter in Moscow (London: Eyre \& Spottiswoode, 1934), 57-61.

67 Ibid., 62.

68 Ibid., 63.

69 Webb and Webb, Soviet Communism, 235.

70 Ibid., 245.

71 This was an attitude shared by many Western proponents of Soviet-style collectivisation. The American enthusiasts N. Buchwald and R. Bishop marvel at the progress made since 1929, when 'the vast majority of the Soviet peasants were individual small-scale farmers' and complain that 'even now many backward peasants are prejudiced against collective large-scale farming' (N. Buchwald and R. Bishop, From Peasant to Collective Farmer (London: Martin Lawrence, 1933), 13.

72 George Orwell, Coming up for Air (London: Penguin Books, 2000), 24.

73 George Orwell, Animal Farm: A Fairy Story (London: Secker \& Warburg, 1987), vol. 8, 50 .

74 Ibid., 43.

75 Ibid., 56.

76 Malcolm Muggeridge, 'The Soviet's War on the Peasants', Fortnightly Review, 33 (May 1933), 558-64 (p. 558).

77 Orwell, Animal Farm, 4.

78 Hilaire Belloc, 'The Restoration of Property: V', English Review, 57:4 (October 1933), 415-24 (p. 422).

79 Unsigned, 'Reconstruction in Russia - IV: Revolution by Tractor', in The Economist (1930), 7-8 (p. 7).

80 Muggeridge, 'The Soviet's War on the Peasants', 558.

81 G. K. Chesterton, The Outline of Sanity: A Rough Sketch of Certain Aspects of the Institution of Private Property (London: Methuen \& Co., 1926), 4-5.

82 Malcolm Muggeridge, 'To the Friends of the Soviet Union', English Review, 58:1 (January 1934), 44-55 (p. 54).

83 George Orwell, Nineteen Eighty-Four (London: Secker \& Warburg, 1997), vol. 9, 214-15.

84 Muggeridge, 'The Soviet's War on the Peasants', 561.

85 The domestic diaries are reproduced in full in George Orwell, Facing Unpleasant Facts, 1937-1939 (London: Secker \& Warburg, 2000), vol. 11, 264-89, 424-68, and George Orwell, A Patriot after All, 1940-1941 (London: Secker \& Warburg, 2000), 317-27.

86 For Orwell's attitude to Chesterton and two contemporary Roman Catholic newspaper columnists, 'Beachcomber' and 'Timothy Shy', who derived their political ideas from Chesterton, see 'As I Please', Tribune, 23 June 1944, in Orwell, I Have Tried to Tell the Truth, 261-3. Orwell did give some credit to the man who had given him his first work as a professional writer, in G.K.'s Weekly: 'Chesterton's vision of life was false in some ways, 
and he was hampered by enormous ignorance, but at least he had courage. He was ready to attack the rich and powerful, and he damaged his career by doing so' (p. 263).

87 Joan Beauchamp, Agriculture in Soviet Russia (London: Victor Gollancz, 1931), 14.

88 Ibid., 18-19.

89 Ibid., 20.

90 Conford, The Origins of the Organic Movement, 194.

91 Cited in Alexandra Harris, Romantic Moderns: English Writers, Artists and the Imagination from Virginia Woolf to John Piper (London: Thames \& Hudson, 2010), 184.

92 Ibid., 184.

93 Viscount Lymington, 'Hammer and Sickle', English Review, 57:2 (August 1933), 185-90 (p. 185).

94 Sybil Oldfield, 'Howard, Louise Ernestine, Lady Howard (1880-1969)', Oxford Dictionary of National Biography (Oxford: Oxford University Press, 2004); http:/ /www.oxforddnb.com/view/article/37576, accessed 6 June 2011.

95 G. T. Wrench, Reconstruction by Way of the Soil (London: Faber, 1946), 179.

96 Ibid., 246.

97 Margaret Cole, Our Soviet Ally: Essays (London: Routledge \& Sons, 1943), 6.

98 Meghnad Desai, Marx's Revenge: The Resurgence of Capitalism and the Death of Statist Socialism (London: Verso, 2002), 99.

99 Cited in Gyorgy Lukács, Lenin: A Study of the Unity of His Thought (London and New York: Verso, 2009), 15.

100 Desai, Marx's Revenge, 101-2.

101 Beauchamp, Agriculture in Soviet Russia, 9-10. 